\title{
Japanese Encephalitis: An Emerging and Spreading Arbovirosis
}

\author{
Shailendra K. Saxena ${ }^{1}$, Sneham Tiwari ${ }^{1}$, Rakhi Saxena ${ }^{1}$, \\ Asha Mathur ${ }^{2}$ and Madhavan P.N. Nair ${ }^{3}$ \\ ${ }^{1}$ Centre for Cellular and Molecular Biology (CCMB-CSIR), \\ Hyderabad (AP), \\ ${ }^{2}$ Department of General Pathology \& Microbiology, \\ Saraswati Medical \& Dental College, Lucknow, \\ ${ }^{3}$ Department of Immunology, Institute of NeuroImmune Pharmacology, \\ Herbert Wertheim College of Medicine, Florida International University, Miami, FL, \\ ${ }^{1,2}$ India \\ 3 USA
}

\section{Introduction}

Japanese encephalitis virus (JEV) is a mosquito-borne flavivirus which causes significant epidemics of encephalitis worldwide with 50,000 cases of encephalitis mostly affecting the children below 10 years of age causing 10,000 deaths annually (Saxena 2008, Diagana et al., 2007). It is well distributed all over Asia and posing threat to many other nations (Yamanaka et al., 2010) JEV strong presence can be felt in the south, southeast, and the east regions of Asia (Shimojima et al., 2011). It is transmitted in an enzootic cycle involving water birds, domestic pigs and rice paddy-breeding mosquito's humans and other non-avian vertebrates. Pigs plays role of major amplifying host (Yamanaka et al., 2010). Humans are accidental/dead end hosts of JEV (Schuh et al., 2009) as their immune system cannot sustain high viral titres. Factors underlying the molecular clinical manifestations and pathogenesis of JEV infection are not completely elucidated. JEV consists of five genotypes: GI, GII, GIII, GIV and GV which are distributed worldwide and phylogenetic studies have revealed that GIII is predominant genotype of JEV with 15 strains in Japan and Korea (Schuh et al., 2009). JEV is expanding to the newer horizons as it is evident from the cases reported from the western parts of the globe. In the present scenario there is no specific treatment against JEV strains, few vaccines are available but they cannot treat all the strains of JEV further studies are require for the proper evaluation and their use in treating JEV infections.

\section{History}

Encephalitis outbreaks have been recorded since early 19th century in countries like Southeast Asia including Japan, Viet Nam, Cambodia, Myanmar, India, Nepal, Malaysia, China, Korea, Taiwan, Thailand and reached to the West including Pakistan and the northeast and southwest of India, also the East (New Guinea), the South (Northern 
Australia Archipelago) and it is estimated theoretically to spread further West (Afghanistan). Between 1978 and 1992, 24 imported cases were reported in above regions due to high transmission.

\begin{tabular}{|l|l|}
\hline Transmission: & $\begin{array}{l}\text { Spread to humans by Culex mosquitoes, which pick up the virus } \\
\text { from infected pigs. }\end{array}$ \\
\hline Symptoms: & $\begin{array}{l}\text { One in 200/800 infected people develop clinical signs like high fever } \\
\text { and nausea. A quarter of patients with symptoms die; a third of } \\
\text { survivors suffer brain damage. }\end{array}$ \\
\hline Treatment: & $\begin{array}{l}\text { Effective anti-viral drugs have yet to be found. Medicines are given } \\
\text { mainly to relieve symptoms. }\end{array}$ \\
\hline Prevention: & $\begin{array}{l}\text { Vaccination for people at risk, eliminate mosquito breeding grounds, } \\
\text { improve drainage, maintain clean piggeries, use insect repellent and } \\
\text { mosquito nets }\end{array}$ \\
\hline
\end{tabular}

Table 1. Japanese Encephalitis: at a glance

Since the 1990s, the transmission of JE virus in humans has extended beyond its original geographical limits as it is evident from the case reports like in 1996, a woman in France suffered from JE after she had visited Thailand, in 1938. JE epidemic reported for first time in restricted seacoast areas of the 'USSR' and it reappeared in 1939. JE was isolated from human in the 'USSR' representing the first genetically characterized strain of JEV from this region, in 1946 major outbreaks of JE were recorded in Korea, in the civilian population in 1949 and among American military personnel in 1950 (Schuh et al., 2009).

Sequencing of JEV strains suggests that JEV is divided into five genotypes (GI-V) (Shimojima et al., 2011), which arose from its ancestor virus in the Indonesia-Malaysia region and evolved into five genotypes: GI, GII, GIII, GIV and GV, out of which GIV and GV are the most divergent which remained confined to the Indonesia-Malaysia region. GI, GII and GIII are the most recent genotypes spread across Asia (Diagana et al., 2007). Phylogenetic characterization in 1930s showed that GIII is predominant genotype of JEV in Japan and Korea since 1935 with 15 strains and GII is present from more than 19 years (Schuh et al., 2009).

GI was first isolated in Cambodia in 1967 and then in China in 1979 while genotype III strains were isolated before the 1970s (Fan et al., 2010). In Vietnam and Japan GIII strains were isolated between 1986 and 1990 and then GI was seen in 1995 and 2002 (Nga et al., 2004) proving that all the strains clustered into two distinct genotypes (III and I) and strains isolated before 1991 belonged to genotype III, whereas those strains isolated after 1994 belonged to genotype I (Ma et al., 2003).

\section{New geographical regions covered}

JEV Sequencing analysis results exhibiting alarming signal to the new regions as the growing evidences suggests the spreading of different JEV groups to the endemic regions Papua New Guinea and Australia GI includes strains isolated from Northern Thailand, 
Cambodia, Korea, China, Japan, Vietnam, Taiwan and Australia between 1967 and the present. GII includes strains isolated from Southern Thailand, Malaysia, Indonesia, Papua New Guinea and Northern Australia between 1970 and 1999, GIII includes strains isolated in temperate regions of Asia from 1935 to the present. GIV includes strains isolated in Indonesia between 1980 and 1981 only, and GV includes a single strain isolated in Singapore in 1952. Sequence analyses of viral genes are further showing that a "genotype shift" from III to I has occurred in Japan since early 1990s, reasons for which remains unclear (Shimojima et al., 2011). Japanese encephalitis (JE) is spreading in the newer areas of northern states of India (Saxena et al., 2006, 2009).

\section{Morphology and properties}

Flavivirus species, which like the Pestivirus and Hepacivirus, is related to the Flaviviridae family. The Flavivirus species not only includes the JE virus but also dengue, yellow fever and tick-borne encephalitis viruses. JE virus is an enveloped RNA virus with ssRNA as genome. It is spheroidal in shape having cubical symmetry, with size of $40-50 \mathrm{~nm}$. Several non-structural and structural genes are present, where the three structural genes are vitally involved in the capsid formation process and are named as core $(\mathrm{C})$, premembrane (prM) and envelope (E). $\mathrm{E}$ is expressed on surface and hence plays an important role in antigenecity.

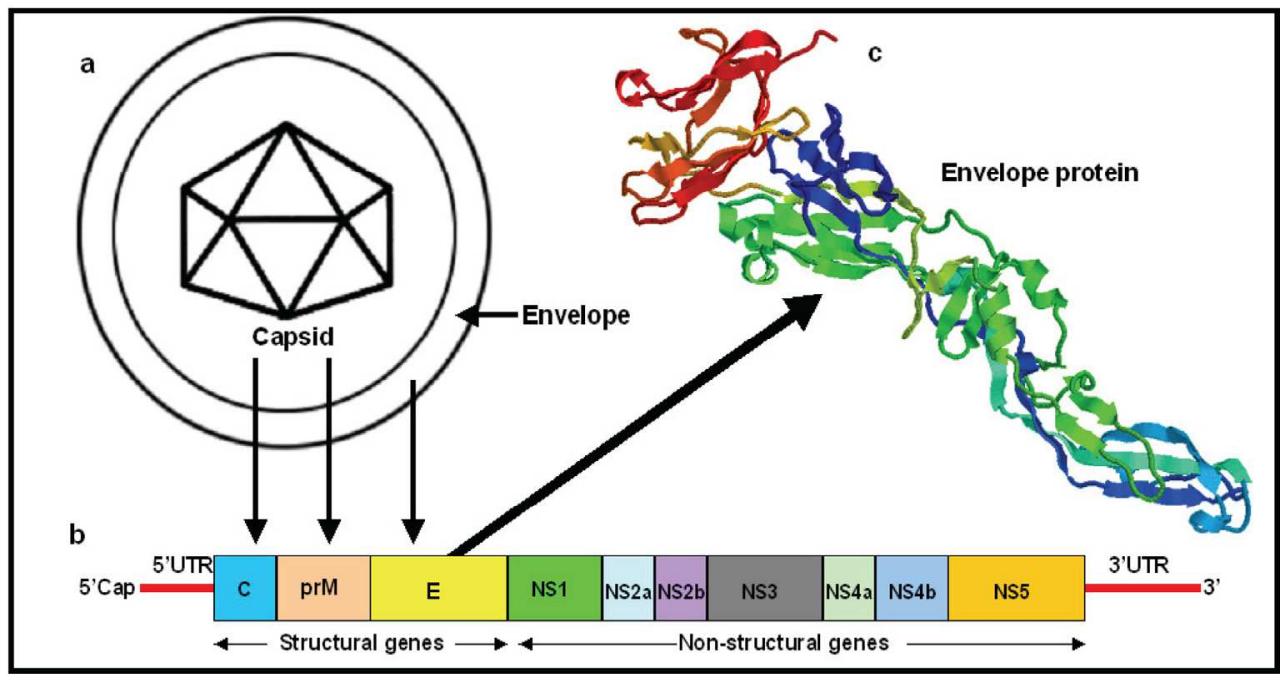

Fig. 1. Japanese encephalitis virus. Japanese encephalitis virus (JEV) structure (A), genomic organization (B), and assimilated structure of the JEV envelope protein (C). JEV genome contains a single open-reading frame (ORF) flanked by 5' and 3' UTRs. ORF consists of three structural genes (C, prM and E) and seven nonstructural (NS1 to NS5) genes

\section{Genome}

JEV isolate from a pool of Culex tritaeniorhynchus collected in southern China had genome consisting of 10,965 nucleotides and included a single open reading frame that encodes a 
3,432-amino-acid polyprotein (Zhang et al., 2009). The RNA genome is about $11 \mathrm{~kb}$ in length having positive polar $5^{\prime}$ cap but no $3^{\prime}$ poly tail. Its genome can be divided into two parts: structural genes (codes for capsid, C; premembrane, prM; and envelope, E) and nonstructural genes (NS1, NS2a, NS2b, NS3, NS4a, NS4b and NS5 are involved in viral replication). NS3 codes for Serine protease and NS5 codes for RNA dependent RNA polymerase, which is cause of mutation, JEV. The functions of other genes are still not understood. Replication of virus happens in cytoplasm and maturation on intracellular membranes (Saxena, 2008).

\section{Transmission cycle}

JEV was isolated from the brain of an encephalitis patient in Tokyo in 1934, and also from C. tritaeniorhyncus mosquitoes in 1938. Studies in Japan, showed pattern of JEV transmission cycle between pigs, mosquitoes, and humans. JE virus is transmitted through a zoonotic cycle between mosquitoes, pigs and water birds. Transmission cycle of JEV was elucidated, where pigs and wild birds played role as amplifying hosts and Cx. tritaeniorhynchus as the primary vector species. Pigs are important for pre-epizootic amplification of virus, although sometimes epidemics may rise even in their absence. Humans and horses also are only incidentally infected and are dead-end hosts of the virus due to low level and transient viremia (Misra and Kalita, 2010).

Numerous studies show similar cycles of JEV transmission, although in some cases virus may be detected in mosquitoes prior to amplification in the pigs. Differences in porcine infection rates within countries can also influence human infection, as was evidenced in Sri Lanka, where porcine synchronous seroconversions led to significant transmission to humans (van den et al., 2009) confirmed by enzyme-linked immunosorbent assay (Rajendran et al., 2003).

\section{Molecular epidemiology}

JEV is classified into 5 genotypes: GI, GII, GIII, GIV, GV. Genotype III (GIII) is widely distributed in Asian countries, including Japan, South Korea, Republic of China, Taiwan, Vietnam, the Philippines, India, Nepal, and Srilanka. By, past decade, JEV GI has been introduced into South Korea, Thailand, and China and has replaced the GIII strains that had been circulating in Japan and Vietnam during the mid-1990s (5). The strains JEV isolated from India till 2007 belonged to GIII (Saxena et al., 2008). JEV emerged in Japan in 1870's, four genotypes of it are recognized presently genotypes I to III are fully sequenced. Complete nucleotide and amino acid sequence of a genotype IV representative, (Indonesian isolate (JKT6468) and it comparison with other fully sequenced genomes has been done. In experimental studies, almost $290 \mathrm{JEV}$ isolates are sequenced showing that all genotypes of JEV circulating in Indonesia- Malaysia region including divergent genotypes GIV and GV which represent the oldest lineages, whereas genotypes GI, GII and GIII circulating in the epidemic and endemic regions are very recent once. Phylogenetic comparisons with other flaviviruses show that it evolved from an African ancestral virus (Solomon et al., 2003). Nucleotide sequencing of C/PrM and E genes, have helped to identify four genotypes of virus. GI includes isolates from northern Thailand, Cambodia, and Korea, GII includes isolates from southern Thailand, Malaysia, Indonesia, and Northern Australia, GIII includes 
Japan, China, Taiwan, the Philippines and Asia, and GIV includes isolates from Indonesia. One strain of JEV (Muar strain) is isolated from Singapore in 1952 from a patient, which may represent a fifth genotype. But in some cases this paradigm is violated as in Vietnam epidemic disease occurs in the north and endemic disease occurs in the south.

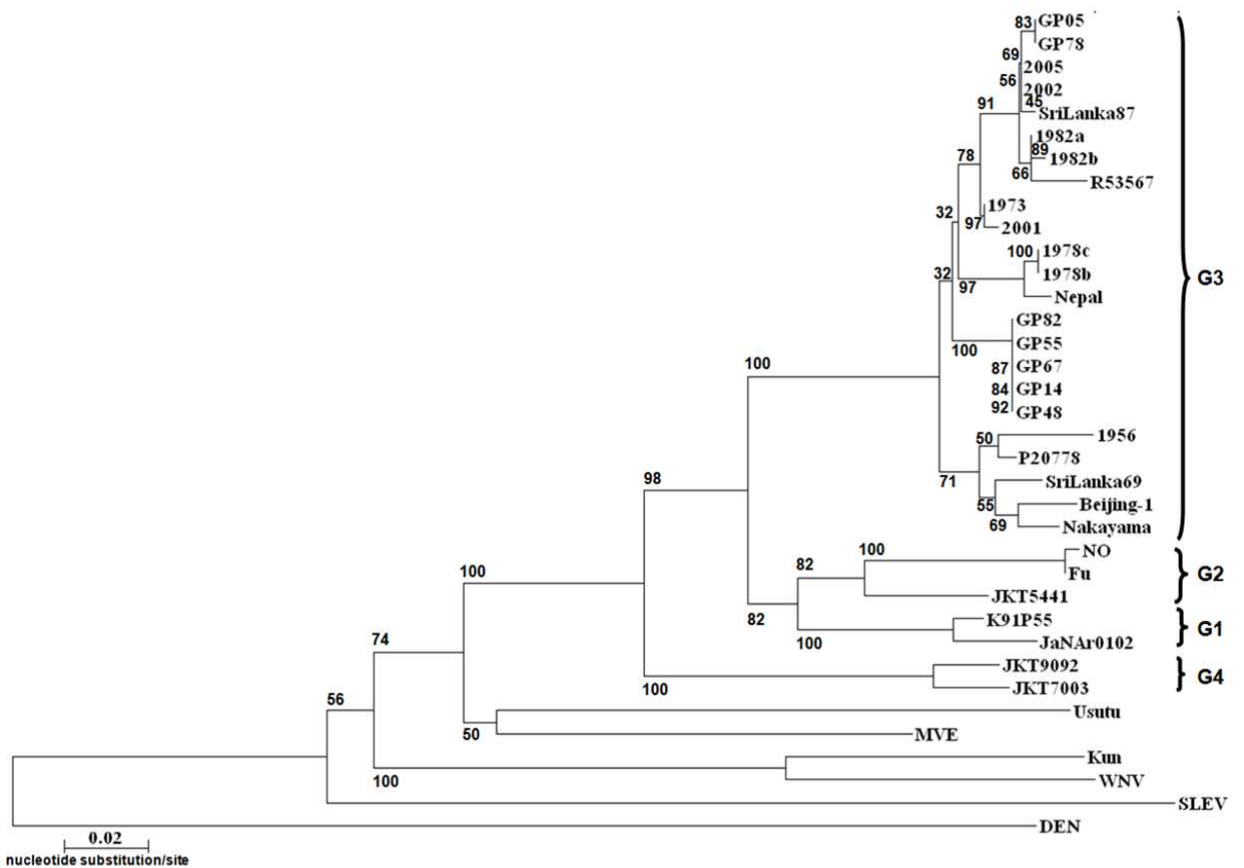

Fig. 2. Sequence phlylogeny of JEV isolates. Sequence phylogeny of Japanese encephalitis virus isolates from the Gorakhpur (India) 2005 epidemic, with reference to other Southeast Asian isolates and flaviviruses based on partial E gene sequence. The tree was generated by neighbor-joining method. Bootstrap values are indicated at the branch points. DEN, WNV, KUN, SLEV and MVE denotes Dengue virus, West Nile virus, Kunjin virus, Saint Louis encephalitis virus and Murray Valley encephalitis virus respectively. (Source: Saxena et al. 2009)

Sequencing and phylogenetic analysis show that JEV strain JKT6468 virus genome is 10,978 nucleotides long and on comparison with 17 sequenced JEV genomes, it was seen that JKT6468 has least similarity, with high nucleotide divergence as compared to GI, GII and G III strains. Analysis has shown that PrM gene has the greatest divergence.

Phylogeny distribution of the JEV strains was based on the E- gene which represents genotypes of the group/groups present in that country. In few instances different genotypes are present within the same country. So the countries are grouped into geographical areas based on geographical proximity, temperature, rainfall, etc which shows dispersed distribution of genotypes (Solomon et al., 2003).

Phylogenetic tree analysis for all JEV strains encircling E, C/PrM, or NS5/3 genes analysis, and GIV, GV comparison with GI, GII, and GIII confirm that the distribution of genotypes 
have true differences. Other group analysis also shows a significant difference in the geographical distribution of genotypes. All genotypes are present in the Indonesia-Malaysia region, but only the most recently evolved genotypes (I, II, and III) are present in the other geographical regions. $\mathrm{C}$ protein and $\mathrm{E}$ protein structural analysis shows that JEV isolate from GIV (JKT7003) is found to retain identical sequence to JKT6468. GIII is the most widely distributed genotype and found in India, and it is predicted to eventually reach Australia, and GII might be found in China or Japan (Solomon et al., 2003).

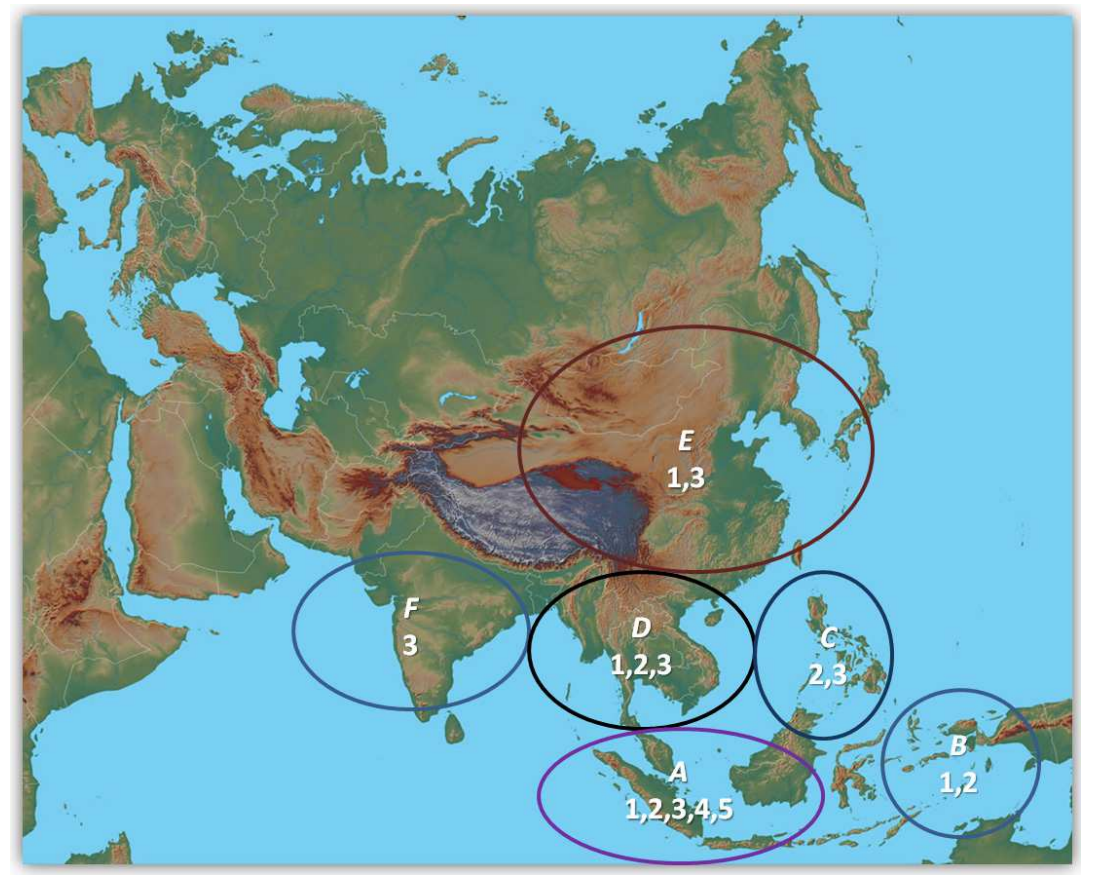

Fig. 3. The geographical distribution and spread of JEV genotypes. Countries are grouped into geographical regions: A, Indonesia (excluding New Guinea) and Malaysia; B, Australia and New Guinea; C, Taiwan and the Philippines; D, Thailand, Cambodia, and Vietnam; E, Japan, Korea, and China; F, India, Sri Lanka, and Nepal. Region A contains all genotypes of JEV, including the oldest. The newer genotypes (I, II, and III) have subsequently spread to other geographical areas. (Source: Solomon et al., 2003)

\section{Epidemiology}

JEV, transmitted by Culex spp mosquitoes, perhaps causes more cases of acute encephalitis than the other arthropod-borne viruses (Richard and John, 2002). JEV is a member of the JEV serological complex, which causes significant morbidity and mortality. The complex consists of eight species and two strains/subtypes including Japanese encephalitis. JEV is the most important member of the JEV group, with an estimated worldwide annual incidence of 45,000 human cases and 10,000 deaths. However, because of insufficient medical facilities and inadequate data collection, JE cases are underreported. Thus, the true annual incidence 
of encephalitis cases is estimated to be closer to 175,000 (van den et al., 2009). JEV is distributed in temperate and tropical areas of eastern and southern Asia. Its geographic range extends from eastern Asia (China, Japan, Korea, maritime Siberia, Taiwan, the Philippines, and Vietnam), to Southeast Asia and northern Australasia (Cambodia, Indonesia, Laos, Malaysia, Papua New Guinea, Thailand, and the Torres Strait islands of northern Australia), and to southern Asia (Bangladesh, Bhutan, India, Myanmar, Nepal, and Sri Lanka). A single report has also suggested that JEV may occur in Pakistan (Solomon and Winter, 2004). JE is largely a disease of rural areas, especially associated with irrigated rice agriculture. In general, two epidemiological patterns of JEV have been recognized: endemic activity in tropical regions, such as southern Thailand, and epidemic activity in temperate and subtropical regions. In endemic areas, no seasonal pattern exists and sporadic cases of encephalitis occur throughout the year, most often in infants and young children, although cases may peak after the onset of the rainy season. Serological tests have shown that by the time children reach adulthood all have been exposed to JEV and possess neutralizing antibodies. Epidemic activity in temperate and subtropical areas occurs most commonly in summer or early autumn after the rainy season, which may extend from spring to late autumn (van den et al., 2009). Because of its prevalence and mortality JE is a major public health problem in endemic-epidemic regions as due to severe susceptibility of the Children and young adults (Diagana et al., 2007). There is a peak in vector density and virus activity during the north-east monsoon period, October-December (Mani et al., 1991 in endemic zones the percentage of JE antibodies increases with age whereas during an epidemic outbreak both adults and children are equally susceptible (Diagana et al., 2007).

\begin{tabular}{|c|c|c|c|}
\hline REGION & AREA & SEASON & HOST/VECTOR \\
\hline $\begin{array}{c}\text { Endemic } \\
\text { region }\end{array}$ & $\begin{array}{c}\text { Southern India, Southern } \\
\text { Vietnam, Southern Thailand, } \\
\text { Philippines, Malaysia and } \\
\text { Indonesia. }\end{array}$ & Rainy & $\begin{array}{c}\text { Mosquitoes, birds, pigs } \\
\text { and human cases are rare. }\end{array}$ \\
\hline $\begin{array}{c}\text { Intermediary } \\
\text { subtropical } \\
\text { region }\end{array}$ & $\begin{array}{c}\text { Includes Northern India, Nepal, } \\
\text { North and Central Burma, } \\
\text { Northern Thailand, Northern } \\
\text { Vietnam, Southern China and } \\
\text { Bangladesh. }\end{array}$ & Rainy & $\begin{array}{c}\text { Epidemics in contrast, } \\
\text { and severe and } \\
\text { concentrated among } \\
\text { children. }\end{array}$ \\
\hline $\begin{array}{c}\text { Temperate } \\
\text { epidemic region }\end{array}$ & $\begin{array}{c}\text { Northern China, Korea, Taiwan } \\
\text { and Southern extremities of } \\
\text { Russia. Also Pakistan, } \\
\text { Afghanistan, Nile valley, } \\
\text { Madagaskar and Oriental Africa. }\end{array}$ & $\begin{array}{c}\text { Summer } \\
\text { and } \\
\text { Autumn }\end{array}$ & $\begin{array}{c}\text { Postulated explanations } \\
\text { are migration of birds, } \\
\text { certain irrigation projects, } \\
\text { animal smuggling and } \\
\text { global warming. }\end{array}$ \\
\hline
\end{tabular}

Table 2. JE is primarily found in South East Asian countries. Three epidemiological regions can be distinguished (Diagana et al., 2007)

From past 75 years the focus was on China and Southeast Asia, but now Japanese encephalitis has expanded westward to India and Pakistan, northward to eastern Russia, eastward to the Philippines, and southward to Australia. In the northern region, epidemics 
occur during the warm summer months, In China, 20000 symptomatic cases are reported annually. The ratio of symptomatic to symptomless infections is around 1:25 to 1:1000. In areas where Japanese encephalitis is common, it is primarily a paediatric disease; however, more cases are seen in adults in new place of exposure (Richard and John, 2002). Occurrence of JE is more closely related to temperature than to humidity in the atmosphere (Misra and Kalita, 2010). JEV has caused major epidemics as it invaded new areas, often enabled by rice culture and amplification in domesticated swine (Weaver and Reisen, 2010).

\section{Geographical distribution}

JEV, the most frequent arboviral cause of encephalitis worldwide, has spread throughout most of Asia and as far south as Australia from its putative origin in Indonesia and Malaysia. Here is a brief outlook:

\subsection{Japan}

Until 1990s, only GIII JE virus was identified in Japan, and then the genotype seemingly shifted to GI. On the basis of molecular epidemiological study in Vietnam, China, and Japan, it was found 8 subgroups of GI JEVs are circulating in East Asia and introduced to Japan through China due to the bird migration and/or infected mosquitoes (Morita, 2009.) JEV infects numerous animal species including humans, horses, pigs, raccoons, wild boars and raccoon dogs recently a study found that it was present in C. tritaeniorhynchus feed on small Asian mongooses on Okinawa Island indicating that they are sensitive to JEV (Saito and Nakata et al., 2009). (Ohno et al., 2009). Distribution of JEV has dispersed to new areas due to migratory birds like wild ducks (Anas poecilorhyncha) which highlight that there may be circulation of JEV in these captured birds. A sero-epizootiological showed several race horses showing high antibody titer (Sugiura and Shimada, 1999). Serum samples of cattle raised in Saitama and Kagoshima Prefectures also showed antibody titers against JEV (Horimoto et al., 1989).

C. tritaeniorhynchus is major mosquito vector in Japan, but recent surveys show that $C$. pipiens and Aedes albopictus as potent competitors too (Konishi, 2005). G1 JEV was also collected from mosquitoes and from swine serum samples collected in Okinawa Island. GI is distributed from northern Thailand to Cambodia and recently expanded to Australia, Vietnam, the Republic of Korea, and Japan (Saito and Taira et al., 2007). Wild boars in the Northern area of the main Okinawa Island in Okinawa Prefecture are infected with JEV which is amplified on pig farms tested for JEV antibody by hemagglutination inhibition assay and IgG enzyme-linked immunosorbent assay (Nidaira et al., 2007).

\subsection{Bali/Java}

Pigs are effective amplifying hosts for JEV, as antibodies to JEV is present majorly in pigs of bali and java (Yamanaka et al., 2010).

\subsection{Thailand}

Here the estimated occurrence is more than 40/1000 in hospitalized patients (Diagana et al., 2007) who serve as evidence of acute flavivirus infection. $10 \%$ of patients in Bangkok 
hospitals and $28 \%$ patients in southern Thailand were found to have JEV infection (Sonja et al., 2010). JEV genotypes studies in pigs and mosquitoes collected near houses of confirmed human GI JEV cases (Nitatpattana et al., 2008). This surveillance study shows an increase of JEV cases during the rainy-seasons.

\subsection{India}

Epidemiological investigations incorporating identification of blood meals of vector mosquitoes proved their involvement in the transmission of JEV from the Kuttanadu area, Kerala. C. tritaeniorhynchus is highly zoophagic and human feeding and also Mansonia indiana and $M a$. uniformis feed on humans showing significant role played by these mosquitoes in the transmission of JEV (Philip Samuel et al., 2008). JEV activity in endemic areas of Tamil Nadu (southern India) is studied, using ELISA (Tewari et al., 2008). JEV was detected using antigen capture ELISA in dry specimens of the mosquito $C$. tritaeniorhynchus in Karnal (Haryana) (Das et al., 2005). A. subpictus serves as a secondary vector in JEV transmission in Cuddalore, Tamil Nadu showing natural transovarial transmission of the virus through A. subpictus (Thenmozhi et al., 2006). JE is found endemic in Cuddalore district, TamilNadu (Kabilan et al., 2004). In a serological survey of birds in Kolar District (Karnataka) by hemagglutination-inhibition test it was showed that bird species such as Pond Herons, Little Egrets Grey Partridges and Quails are infected with JEV and play role in the JEV infections (Jamgaonkar et al., 2003) (Rajendran et al., 2003). Three cases of JE were reported for the first time from two villages in Krishnagiri Health Unit district of Tamil Nadu. Sixteen serum samples from patients were sent to the Department of Virology, Calcutta, which is first documentation of concomitant JEV and HIV infection in the eastern India (Neogi et al., 1998).

\subsection{Malaysia}

JEV is an important encephalitis virus in Malaysia, which was thoroughly studied in Sarawak, Malaysia. JEV is endemic in Sarawak, with cases occurring throughout the year (Wong et al., 2008) a few cases have been reported in tropical Asian countries (Kari et al., 2006). JEV is an important causative agent of viral encephalitis among pediatric admissions in Penang, Malaysia was proved by an IgM capture ELISA (Cardosa et al., 1995). Studies also show encephalitis in Perak, Malaysia with data showing titers of neutralizing antibodies against JEV (Cardosa et al., 1991). JE epidemic occurs sporadically throughout the year and is generally asymptomatic (Sinniah, 1989).

\subsection{Philippines}

A long-term study in Philippines confirmed acute cases of Japanese encephalitis via IgMcapture ELISA, which detects anti-JEV immunoglobulin $\mathrm{M}$ (IgM) in cerebrospinal fluid (CSF) samples (Natividad et al., 2006) (Kari et al., 2006). Mosquitoes were collected from Tagudin, Ilocos Sur Province, Philippines, and found positive for the presence of JEV by the help of microneutralization test (Trosper et al., 1980).

\subsection{Korea}

Serological survey of JEV infection in goats in Korea provide incidence of positive cases indicating that JEV infection is frequent in goat farms in Korea (Yang et al., 2007). 


\subsection{Nepal}

Regional survey conducted in Nepal for antibody to JEV in pigs, ducks and horses showed positive result for the presence of antibodies against JEV (Pant et al., 2006). Intense transmission of JEV in the area of the British Military Cantonment at Dharan was confirmed by serological studies from the healthy Nepalese from Dharan and animals from the Cantonment farm which indicates rapid transmission of JEV occuring within the Cantonment area. (Henderson, 1983). The first proven outbreak of JE in Kathmandu Valley of Nepal was in 1995 (Zimmerman et al., 1997). Viral studies of serum and cerebro-spinal fluid (CSF) confirm JEV as the causative agent (McCallum, 1991).

\subsection{Indonesia}

Geographical range of endemic JE is much vast than estimated (Kari et al., 2006), It is no longer rare to tropical Asia, a study was conducted to measure the prevalence with hemagglutination-inhibition (HI) and neutralizing antibodies against JEV in horses of Java, Indonesia indicating a high risk of JEV infection (Widjaja et al., 1995).

\subsection{Singapore}

Detection of neutralizing antibodies to JEV in a population of wild boars, as well as two human cases of JE in Singapore indicates that JEV may still be actively transmitted in the peripheral part of the Singapore Island (Ting et al., 2004). A study was conducted to determine the presence of prevalence with hemagglutination inhibition (HI) and neutralization antibodies against JEV in wild pigs of an island in Singapore showing positive results for antibodies against JEV (See et al., 2002).

\subsection{Cambodia}

JEV is an important causative agent of acute encephalitis in Cambodia, this issue still remains unclear, but some survey shows that infection with JEV is the principal cause for it (Srey et al., 2002).

\subsection{Taiwan}

Sero epidemiological survey of JEV in Taiwan indicated that the JEV vaccination, in conjunction with JEV natural infection, maintains high JEV Neutralizing (NT) antibody level among rural children of Taiwan (Hsu et al., 1997) showing confirmed Japanese encephalitis (JE) cases (Ku et al., 1994).

\subsection{Bangkok}

Study of JE was conducted in suburban Bangkok and the primary vector species are found to be C. gelidus and C. tritaeniorhynchus. Human cases occurred from May-July (Gingrich et al., 1987). In a 5 year study, 121 encephalitis patients were admitted to Bangkok Children's Hospital out of which 79 were proved to be JE (Thisyakorn and Nimmannitya, 1985).

\subsection{Spain}

JEV antigenic complex of flaviviruses are recognized as emerging and re-emerging pathogens. Their circulation is recently detected in different mosquito and vertebrate species 
in several European countries. Serosurvey using a competitive enzyme-linked immunosorbent assay showed seropositivity in Common Coot (Fulica sp.), Montagu's Harrier (Circus sp.), Black Kite (Milvus sp.), Black Vulture, (Coragyps sp.), Bonelli's Eagle (Aquila fasciata), Spanish Imperial Eagle (Aquila adalberti), Egyptian Vulture (Neophron percnopterus), and Eurasian Spoonbill (Platalea leucorodia) in autumn season. Real-time reverse transcription-polymerase chain reaction indicated that JEV antigenic group circulates in migratory and resident wild bird species (García-Bocanegra et al., 2001).

\subsection{Vietnam}

JE is an important public health problem in Vietnam (Yen et al., 2010). Many patients are suspected with CNS Infections and children infected with JE virus (JEV), suffered from hemiparesis, meningism including limb paralysis and some of them subsequently became encephalopathic (Solomon T et al., 2008).

\subsection{Hawai Island}

JEV is emerging arboviruses which is undergoing intercontinental expansion; it is transmitted between mosquito vectors and vertebrate reservoir hosts, including birds. A potential route of JEV introduction from Asia to western North America is via the Hawaiian archipelago also frequent air traffic from both Asia and North America to Hawai increases the chances of flaviviral infection (Nemeth et al., 2010).

\subsection{Central China}

Studies with four strains of JEV isolated from CSF of aborted fetuses collected in central China through RT-PCR and sequencing, suggested that GIII is the major subtype of JEV, circulating in central China, Fujian, and Heilongjiang (Fan et al., 2010). However, Shanghai isolates belong to GI ( $\mathrm{Li}$ et al., 2009). GI strain is distributed well in Southeast Asian countries, whereas, genotype III strains in Northern Asia (Fan et al., 2010). Viral encephalitis emerged in Yuncheng city, Shanxi Province was proved to be Japanese encephalitis B (Zhang et al., 2008). Recent JEV isolates from China are divided into two genotypes, genotype 1 and genotype 3; recent JEV isolates from China are grouped into the same clusters within GI and GIII but GIII strains are ancient than GI (Wang et al., 2007).

\subsection{Australia}

Domestic pigs, act as the amplifying host of JEV (van den Hurk et al., 2008). It appears annually in the Torres Strait in far northern Queensland, Australia, and is proving a threat for invasion in Australian mainland. Sentinel pigs have a tendency to develop detectable viremias to JEV. Since pigs are amplifying hosts for JEV, they are health risk to the public (Ritchie et al., 2007) (van den Hurk et al., 2008). Culex mosquitoes in Cape Town (van den Hurk et al., 2006) and Saibai Islands may be responsible for JEV activity (Johansen et al., 2004). Still there are no evidences found to prove JE responsible for enzootic transmission cycles on western Cape York (Johansen et al., 2003). In Western Province of Papua New Guinea, pigs and marsupials were studied indicating marsupials as poor JE virus host (van den Hurk et al., 2003), but they may play a vital role (Mackenzie et al., 2003). Collections from Badu Island community yielded C. annulirostris (van den Hurk et al., 2001) and from Croydon, Normanton and Karumba yielded C. annulirostris skuse and C. palpalis mosquitoes 
(van den Hurk et al., 2002); (van den Hurk et al., 2003). Mosquitoes from Cape York Peninsula (van den Hurk et al., 2001) and north Queensland appear to have limited transmission on the mainland, nucleotide sequencing indicate that cyclonic winds carried infected mosquitoes from Papua New Guinea to these places (Hanna et al., 1991) and JEV is demonstrating an emergence in the southern part of New Guinea Island (Spicer et al., 1999).

\section{Symptoms}

Symptomatic JEV infection shows febrile illness, aseptic meningitis or encephalitis which manifests sensorium, seizures and focal neurological deficit and acute flaccid paralysis. A wide variety of movement disorders like Parkinsonian features and dystonia are also seen (Solomon et al., 2004). JE mainly affects thalamus, corpus striatum, brainstem and spinal cord. In some incidences co-infection of JE and cysticercosis occurs because of the involvement of pigs (Misra and Kalita, 2010). JEV is also associated with reproductive failure in swine (Lim et al., 2007) and also causes fever, headache aseptic meningitis,change of consciousness convulsions, vomiting and encephalitis (Yang et al., 2007). Surveys suggest shift clinical manifestation from encephalitis to meningitis (Konishi, 2005). Death is presumed to result from infection, dysfunction and destruction of neurons. Patients for seizures and clinical signs of brainstem herniation are also reported. Findings suggest that seizures and raised ICP may be important causes of death in case of JE (Solomon et al., 2002). The neurologic signs like meningeal signs, hyperreflexia, Babinski's sign, hemiplegia, papilledema and other cranial nerve palsies are also seen. Most children have blood leukocytosis with predominant neutrophils (Poneprasert, 1989; Srivastava et al., 1999).

\section{JEV human infections}

Infections of humans with JEV produce vast clinical manifestations, ranging from asymptomatic infection like mild febrile illness, acute and lethal meningomyeloencephalitis. Most infections are asymptomatic and cause a nonspecific influenza-like illness. The ratio of symptomatic to asymptomatic cases has occasionally been higher. Sequelae are more frequent in patients having severe and prolonged acute diseases along with coma and focal neurological deficits.

\section{Laboratory diagnosis}

Laboratory diagnosis of JE is by IgM capture ELISA, which has high sensitivity and specificity. In the absence of specific antiviral therapy, JE is managed by symptomatic and supportive therapies and preventive measures. Encephalitis is an unusual manifestation of human viral infection, whereas many individuals develop systemic viral infections, only a few develop symptomatic infection of the central nervous system (Whitley and Gnann, 2002).

\section{Risk}

JEV may become epizootic and epidemic if it is introduced unintentionally for commercial use or intentionally for nefarious purposes. Even global warming may also facilitate the 
distributions of arboviruses, expanding northward into southern Europe, increasing transmission season and capacity of vectors. Greatest health risk of arboviral emergence is due to extensive tropical urbanization and the colonization by highly anthropophilic mosquitoes. Sustained endemic arbovirus transmission, adequate human viremia and vector competence is the minimal requirement to become major human pathogens (Weaver and Reisen, 2010). Recent global warming trends affect vector population dynamics and disease transmission which is measured by hemagglutination-inhibition (HI) antibodies titre tests (Yang et al., 2008). Studies show incidence of dengue virus (DEN) infections in a cohort of Dutch short-term travellers who travelled to endemic areas in Asia, post-travel serological studies were done by DEN immunoglobulin M (IgM) showing that DEN infections are frequent in travellers to endemic areas in Asia (Cobelens et al., 2002).

\section{Host immune response}

The factors which govern the clinical presentations and outcome of flavivirus infections are not very well understood, but studies are going on at viral virulence determinants and the host immune response. Distribution of the four genotypes across Asia may relate to the different clinical epidemiology. However nucleotide sequence studies of oldest lineages virus, and phylogenetic analyses of all JEV strains, suggest that the origin is best in the Indonesia-Malaysia region (where all genotypes have been found), and there is spread of the more recent genotypes to new geographical areas. Innate immunity, as evidenced by interferon alpha levels, plays an important role in JEV and other flaviviruses. Cellular immunity is less characterized, but CD8+ and CD4+ $\mathrm{T}$ cells may play important role (Solomon and Winter, 2004; Tandon et al. 2002). A failure of the humoral immune response may be associated with death from encephalitis caused by JEV.

\section{Future risk}

There is potential risk of introduction and establishment of JEV in newer areas of the world. JEV is endemic to Asia and when transmitted to humans (accidental host), may lead to JE, mostly in children with a fatality rate up to $30 \%$. The geographical expansion of JEV in Asia shows the ability of arboviruses to rapidly extend their distributions. As for example, studies have shown that California is at risk for JEV introduction because it functions as a hub for international travel and commerce with Asia, indirectly allowing the introduction of mosquitoes infected with JEV. Introduction of JEV in California, might pose challenge to the health sector due to establishment of susceptible mosquito vectors and vertebrate will lead to the flaws in the surveillance of JEV, and cross reactivity of serological test between JEV and other flaviviruses, and may be JE may not be considered as a possible diagnosis, these all will lead to delay and this delay in detection of JEV may pose challenge in eradicating the virus from California so there is need of considerations for future control efforts if JEV emerges in the United States (Nett et al., 2009).

In the last decade had introduction of huge number of encephalitic viruses and the emergence or spread in the Southeast Asian and Western Pacific regions. JEV has spread its wings through the Indonesian archipelago to Papua New Guinea and to the islands of the Torres Strait of northern Australia, and also to Pakistan and new areas in the Indian 
subcontinent (Mackenzie, 2005). The incidence of JE in recent times is showing an increasing trend. It appears that JE may become one of the major public health problems in India considering the proportion of JEV infections among the encephalitic children (Kabilan et al., 2004).

\section{Prevention/vaccination}

Vaccination proves to be the best to protect the individual against any disease. In the case of $\mathrm{JE}$, it is essential to immunize the pigs also to interrupt the transmission cycle (Kabilan et al., 2004). Japanese racehorses are vaccinated with inactivated JE vaccine every year which lessens up the JE cases (Konishi et al., 2004). Screening of goats and cattle are also suggested for JE infection risk to the human population (Rajendran et al., 2003). JEV and JEV-induced macrophage-derived factor (MDF) can modulate nitric oxide synthase (NOS) activity in brain and tumor necrosis factor-alpha (TNF-alpha) (Khanna et al., 1991 and Mathur et al 1992; Saxena et al., 2001) NOS activity gets enhanced in JEV or JEV-induced MDF-treated mice (Saxena et al., 2001). The enhanced level of TNF-alpha correlates well with enhanced inducible nitric oxide synthetase (iNOS) activity, thus provide evidence for protective role of iNOS during JEV infection and hence indicate that iNOS may be a key mediator in host innate immune response (Saxena et al., 2000, 2001, 2003). Administration of inactivated mouse-brain derived JEV were reported in Japan and the United States which had some problem (Takahashi et al., 2000). There is continuous need for constant surveillance and monitoring so as to prevent future large outbreaks (Victor et al., 2000). In fact, three doses of mouse-brain vaccine are enough to protect children against the local Taiwan JEV and choice of selection for best strain for a JE vaccine depends on level of $\mathrm{Nt} \mathrm{Ab}$ [neutralisation antibody] it induces, the molecular epidemiology and antigenic variation. The future vaccine must produce better B- and T-cell memory in the vaccinated populations ( $\mathrm{Ku}$ et al., 1994) Vaccinia virus (NYVAC) was engineered to express the JEV prM, E, and NS1 genes, the recombinant viruses were tested as vaccine candidates in pigs showing that after immunization, JEV levels detected in the were reduced demonstrating the ability of NYVAC-vectored recombinants to protect pigs from JEV viremia (Konishi et al., 1992). Extracellular HeLa cells produce extracellular subviral particles which were infected with a recombinant vaccinia virus encoding the prM and E gene and were purified. Mice when received a single inoculation of the purified extracellular particles were fully protected against LD50 of JEV (Konishi and Pincus et al., 1992). Although vaccinia recombinants expressing NS1 can provide some protection from lethal JEV infection, recombinants expressing prM and $\mathrm{E}$ have higher levels of protective immunity (Konishi et al., 1991). Antipyretics, anticonvulsants, anticerebral edema agents, adequate respiration and nutrition and physical and occupational therapies are needed by patients (Poneprasert, 1989).

\section{Acknowledgment}

Authors are grateful to Dr Ch. Mohan Rao, Director, Centre for Cellular and Molecular Biology (Council of Scientific and Industrial Research, India), for the encouragement and support for this work. We also thank Mr ML Arvinda Swamy and Ms Kamakshi Dandu for reviewing this manuscript. A NIH Award (R37DA025576) supports S.K.S. and M.P.N. 


\section{References}

Cardosa, M.J., Choo, B.H. and Zuraini, I. (1991). A serological study of Japanese encephalitis virus infections in northern Peninsular Malaysia. Southeast Asian J Trop Med Public Health 22(3): 341-346.

Cardosa, M.J., Hooi, T.P. and Kaur, P. (1995). Japanese encephalitis virus is an important cause of encephalitis among children in Penang. Southeast Asian J Trop Med Public Health 26(2): 272-275.

Cobelens, F.G., Groen, J., Osterhaus, A.D., Leentvaar-Kuipers, A., Wertheim-van Dillen, P.M. and Kager, P.A. (2002). Incidence and risk factors of probable dengue virus infection among Dutch travellers to Asia. Trop Med Int Health 7(4): 331-338.

Das, B.P., Sharma, S.N., Kabilan, L., Lal, S. and Saxena, V.K. (2005). First time detection of Japanese encephalitis virus antigen in dry and unpreserved mosquito Culex tritaeniorhynchus Giles, 1901, from Karnal district of Haryana state of India. J Commun Dis. 37(2): 131-133.

Diagana, M., Preux, P.M. and Dumas, M. (2007). Japanese encephalitis revisited. J Neurol Sci. 262(1-2): 165-170.

Fan, J.M., Luo, J., Chen, L., Teng, M., Bu, D., Wang, F.Y., Wang, L., Wang, C.Q. and Zhang, G.P. (2010). Genetic analysis of strains of Japanese Encephalitis Virus isolated from swine in central China. Virus Genes. 40(3): 357-361.

García-Bocanegra, I., Busquets, N., Napp, S., Alba, A., Zorrilla, I., Villalba, R. and Arenas, A. (2010). Serosurvey of West Nile Virus and Other Flaviviruses of the Japanese Encephalitis Antigenic Complex in Birds from Andalusia, Southern Spain. Vector Borne Zoonotic Dis. Dec 13, 2010. [Epub ahead of print].

Gingrich, J.B., Nisalak, A., Latendresse, J.R., Pomsdhit, J., Paisansilp, S., Hoke, C.H.,Chantalakana, C., Satayaphantha, C. and Uechiewcharnkit, K. (1987). A longitudinal study of Japanese encephalitis in suburban Bangkok, Thailand. Southeast Asian J Trop Med Public Health. 18(4): 558-566.

Gunakasem, P., Chantrasri, C., Simasathien, P., Chaiyanun, S., Jatanasen, S. and Pariyanonth, A. (1981). Surveillance of Japanese encephalitis cases in Thailand. Southeast Asian J Trop Med Public Health. 12(3): 333-337.

Hanna, J.N., Ritchie, S.A., Phillips, D.A., Lee, J.M., Hills, S.L., van den Hurk, A.F., Pyke, A.T., Johansen, C.A. and Mackenzie, J.S. (1999). Japanese encephalitis in north Queensland, Australia, 1998. Med J Aust. 170(11): 533-536.

Henderson, A. (1983). Encephalitis in Nepal: the visitation of the goddess of the forest. $J R$ Army Med Corps 129(3): 156-162.

Horimoto, M., Sakai, T. and Goto, H. (1989). [Japanese encephalitis virus infection in cattle:a serological survey in Saitama and Kagoshima Prefectures]. Kansenshogaku Zasshi. 63(1): 10-14.

Hsu, L.C., Wu, Y.C., Lin, S.R., King, C.C., Ho, M.S., Lu, C.F., Hsu, H.M., Chen, K.T. and Horng, C.B. (1997). [Seroepidemiology of Japanese encephalitis viral infection among 3-6 years old children from mountainous and plains townships located in the northern, central, southern and eastern Taiwan]. Zhonghua Min Guo Wei Sheng Wu Ji Mian Yi Xue Za Zhi 30(3): 194-206.

Jamgaonkar, A.V., Yergolkar, P.N., Geevarghese, G., Joshi, G.D., Joshi, M.V. and Mishra, A.C. (2003). Serological evidence for Japanese encephalitis virus and West Nile virus infections in water frequenting and terrestrial wild birds in 
Kolar District,Karnataka State, India. A retrospective study. Acta Virol. 47(3): 185-188.

Johansen, C.A., Nisbet, D.J., Foley, P.N., Van Den Hurk, A.F., Hall, R.A., Mackenzie, J.S. and Ritchie, S.A. (2004). Flavivirus isolations from mosquitoes collected from Saibai Island in the Torres Strait, Australia, during an incursion of Japanese encephalitis virus. Med Vet Entomol. 18(3): 281-287.

Johansen, C.A., Nisbet, D.J., Zborowski, P., van den Hurk, A.F., Ritchie, S.A. and Mackenzie, J.S. (2003). Flavivirus isolations from mosquitoes collected from western Cape York Peninsula, Australia, 1999-2000. J Am Mosq Control Assoc. 19(4): 392-396.

Kabilan, L., Rajendran, R., Arunachalam, N., Ramesh, S., Srinivasan, S., Samuel, P.P. and Dash, A.P. (2004). Japanese encephalitis in India: an overview. Indian J Pediatr. 71(7): 609-615.

Kabilan, L., Vrati, S., Ramesh, S., Srinivasan, S., Appaiahgari, M.B., Arunachalam, N., Thenmozhi, V., Kumaravel, S.M., Samuel, P.P. and Rajendran, R. (2004). Japanese encephalitis virus (JEV) is an important cause of encephalitis among children in Cuddalore district, Tamil Nadu, India. J Clin Virol. 31(2): 153-159.

Kari, K., Liu, W., Gautama, K., Mammen, M.P. Jr., Clemens, J.D., Nisalak, A., Subrata, K., Kim, H.K. and Xu, Z.Y. (2006). A hospital-based surveillance for Japanese encephalitis in Bali,Indonesia. BMC Med. 7; 4: 8.

Khanna, N., Agnihotri, M., Mathur, A., and Chaturvedi, U.C. (1991) Neutrophil chemotactic factor produced by Japanese encephalitis virus stimulated macrophages. Clin Exp Immunol. 86(2): 299-303.

Konishi, E., Pincus, S., Fonseca, B.A., Shope, R.E., Paoletti, E. and Mason, P.W. (1991). Comparison of protective immunity elicited by recombinant vaccinia viruses that synthesize E or NS1 of Japanese encephalitis virus. Virology 185(1): 401-410.

Konishi, E., Pincus, S., Paoletti, E., Laegreid, W.W., Shope, R.E. and Mason, P.W. (1992). A highly attenuated host range-restricted vaccinia virus strain, NYVAC, encoding the prM, E, and NS1 genes of Japanese encephalitis virus prevents JEV viremia in swine. Virology. 190(1): 454-458.

Konishi, E., Pincus, S., Paoletti, E., Shope, R.E., Burrage, T. and Mason, P.W. (1992). Mice immunized with a subviral particle containing the Japanese encephalitis virus prM/M and E proteins are protected from lethal JEV infection. Virology. 188(2): 714720 .

Konishi, E., Shoda, M. and Kondo, T. (2004). Prevalence of antibody to Japanese encephalitis virus nonstructural 1 protein among racehorses in Japan: indication of natural infection and need for continuous vaccination. Vaccine. 22(9-10): 10971103.

Konishi, E. (2005). [Clinical and epidemiological aspects of Japanese encephalitis]. Nippon Rinsho 63(12): 2138-2142.

Ku, C.C., King, C.C., Lin, C.Y., Hsu, H.C., Chen, L.Y., Yueh, Y.Y. and Chang, G.J. (1994). Homologous and heterologous neutralization antibody responses after immunization with Japanese encephalitis vaccine among Taiwan children. J Med Virol. 44(2): 122-131.

Li, Y.T., Zhu, Y.Y. and Jin, B.H. (2009). Epidemiological characteristics of Japanese encephalitis in Shanghai. Zhongguo Yi Miao He Mian Yi. 15(6): 507-10, 561. 
Lim, S.I., Kweon, C.H., Tark, D.S., Kim, S.H. and Yang, D.K. (2007). Sero-survey on Aino, Akabane, Chuzan, bovine ephemeral fever and Japanese encephalitis virus of cattle and swine in Korea. J Vet Sci. 8(1): 45-49.

Lindenbach, B. D., and Rice, C.M. (2001). Flaviviridae: the viruses and their replication. In D. M. Knipe and P. M. Howley (ed.), Fields virology, 4th ed., vol. I: 991-1042.

Ma, S.P., Yoshida, Y., Makino, Y., Tadano, M., Ono, T. and Ogawa, M. (2003). Short report: a major genotype of Japanese encephalitis virus currently circulating in Japan. Am J Trop Med Hyg. 69(2): 151-154.

Mackenzie, J.S. (2005). Emerging zoonotic encephalitis viruses: lessons from Southeast Asia and Oceania. J Neurovirol. 11(5): 434-440.

Mackenzie, J.S., Johansen, C.A., Ritchie, S.A., van den Hurk, A.F. and Hall, R.A. (2002). Japanese encephalitis as an emerging virus: the emergence and spread of Japanese encephalitis virus in Australasia. Curr Top Microbiol Immunol. 267: 49-73.

Mani, T.R., Rao, C.V., Rajendran, R., Devaputra, M., Prasanna, Y., Hanumaiah., Gajanana, A. and Reuben, R. (1991). Surveillance for Japanese encephalitis in villages near Madurai, Tamil Nadu, India. Trans R Soc Trop Med Hyg 85(2): 287-291.

Mathur, A., Khanna, N. and Chaturvedi, U.C. (1992). Breakdown of blood-brain barrier by virus-induced cytokine during Japanese encephalitis virus infection. Int $J$ Exp Pathol. 73(5): 603-611.

McCallum, J.D. (1991). Japanese encephalitis in southeastern Nepal: clinical aspects in the 1986 epidemic. J R Army Med Corps. 137(1): 8-13.

Misra, U.K. and Kalita, J. (2010). Overview: Japanese encephalitis. Prog Neurobiol. 91(2): 108120.

Natividad, F.F., Daroy, M.L., Alonzo, M.T., Matias, R.R., Suarez, L.A. and Inoue, S. (2006). Use of IgM-capture ELISA for confirmation of Japanese encephalitis infections in the Philippines. Southeast Asian J Trop Med Public Health. 37(Suppl 3): 136-139.

Nemeth, NM., Bosco-Lauth, AM., Sciulli, RH., Gose, RB., Nagata, MT. and Bowen RA. (2010). Serosurveillance for Japanese encephalitis and West Nile viruses in resident birds in Hawai'i. J Wildl Dis. 46(2): 659-664.

Neogi, D.K., Bhattacharya, N., Chakrabarti, T. and Mukherjee, K.K. (1998). Detection of HIV seropositivity during an outbreak of Japanese encephalitis in Manipur. J Commun Dis. 30(2): 113-116.

Nerome, R., Tajima, S., Takasaki, T., Yoshida, T., Kotaki, A., Lim, C.K., Ito, M., Sugiyama, A., Yamauchi, A., Yano, T., Kameyama, T., Morishita, I., Kuwayama, M., Ogawa, T., Sahara, K., Ikegaya, A., Kanda, M., Hosoya, Y., Itokazu, K., Onishi, H., Chiya, S., Yoshida, Y., Tabei, Y.,Katsuki, K., Tabata, K., Harada, S. and Kurane, I. (2007). Molecular epidemiological analyses of Japanese encephalitis virus isolates from swine in Japan from 2002 to 2004. J Gen Virol. 88(Pt 10): 2762-2768.

Nett, R.J., Campbell, G.L. and Reisen, W.K. (2009). Potential for the emergence of Japanese encephalitis virus in California. Vector Borne Zoonotic Dis. 9(5): 511-517.

Nga, P.T., del Carmen Parquet, M., Cuong, V.D., Ma, S.P., Hasebe, F., Inoue, S., Makino, Y., Takagi, M., Nam, V.S. and Morita, K. (2004). Shift in Japanese encephalitis virus (JEV) genotype circulating in northern Vietnam: implications for frequent introductions of JEV from Southeast Asia to East Asia. J Gen Virol. 85(Pt 6): 16251631. 
Nidaira, M., Taira, K., Itokazu, K., Kudaka, J., Nakamura, M., Ohno, A. and Takasaki, T. (2007). Survey of the antibody against japanese encephalitis virus in Ryukyu wild boars (Sus scrofa riukiuanus) in Okinawa, Japan. Jpn J Infect Dis. 60(5): 309-311.

Nitatpattana, N., Dubot-Pérès, A., Gouilh, M.A., Souris, M., Barbazan, P., Yoksan, S., deLamballerie, X. and Gonzalez, J.P. (2008). Change in Japanese encephalitis virus distribution, Thailand. Emerg Infect Dis (11): 1762-1765.

Olsen, S.J., Supawat, K., Campbell, A.P., Anantapreecha, S., Liamsuwan, S., Tunlayadechanont, S., Visudtibhan, A., Lupthikulthum, S., Dhiravibulya, K., Viriyavejakul, A., Vasiknanonte, P., Rajborirug, K., Watanaveeradej, V., Nabangchang, C., Laven, J., Kosoy, O., Panella, A., Ellis, C., Henchaichon, S., Khetsuriani, N., Powers, A.M., Dowell, S.F. and Fischer, M. (2010). Japanese encephalitis virus remains an important cause of encephalitis in Thailand. Int J Infect Dis. 14(10): e888-892.

Pandey, B., Yamamoto, A., Morita, K., Kurosawa, Y., Rai, S., Adhikari, S., Kandel, P. and Kurane, I. (2003). Serodiagnosis of Japanese encephalitis among Nepalese patients by the particle agglutination assay. Epidemiol Infect. 131(2): 881-885.

Pant, G.R., Lunt, R.A., Rootes, C.L. and Daniels, P.W. (2006). Serological evidence for Japanese encephalitis and West Nile viruses in domestic animals of Nepal. Comp Immunol Microbiol Infect Di.s 29(2-3): 166-175.

Philip Samuel, P., Arunachalam, N., Hiriyan, J. and Tyagi, B.K. (2008). Host feeding pattern of Japanese encephalitis virus vector mosquitoes (Diptera: Culicidae) from Kuttanadu, Kerala, India. J Med Entomol. 45(5): 927-932.

Poneprasert, B. (1989). Japanese encephalitis in children in northern Thailand. Southeast Asian J Trop Med Public Health. 20(4): 599-603.

Rajendran, R., Thenmozhi, V., Tewari, S.C., Balasubramanian, A., Ayanar, K., Manavalan, R., Gajanana, A., Kabilan, L., Thakare, J.P. and Satyanarayana, K. (2003). Longitudinal studies in South Indian villages on Japanese encephalitis virus infection in mosquitoes and seroconversion in goats. Trop Med Int Health. 8(2): 174181.

Ritchie, S.A., van den Hurk, A.F., Zborowski, P., Kerlin, T.J., Banks, D., Walker, J.A., Lee, J.M., Montgomery, B.L., Smith, G.A., Pyke, A.T. and Smith, I.L. (2007). Operational trials of remote mosquito trap systems for Japanese encephalitis virus surveillance in the Torres Strait, Australia. Vector Borne Zoonotic Dis 7(4): 497-506.

Saito, M., Nakata, K., Nishijima, T., Yamashita, K., Saito, A. and Ogura, G. (2009). Proposal for Japanese encephalitis surveillance using captured invasive mongooses under an eradication project on Okinawa Island, Japan. Vector Borne Zoonotic Dis. 9(3): 259266.

Saito, M., Osa, Y. and Asakawa, M. (2009). Antibodies to flaviviruses in wild ducks captured in Hokkaido, Japan: risk assessment of invasive flaviviruses. Vector Borne Zoonotic Dis. 9(3): 253-258.

Saxena, S.K. (2008). Japanese encephalitis: perspectives and new developments. Future Neurol. 3(5): 515-521.

Saxena, S.K., Mathur, A. and Srivastava, R.C. (2001). Induction of nitric oxide synthase during Japanese encephalitis virus infection: evidence of protective role. Arch Biochem Biophys. 391(1): 1-7. 
Saxena, S.K., Mathur, A., and Srivastavam R.C. (2003). Inhibition of Japanese encephalitis virus infection by diethyldithiocarbamate is independent of its antioxidant potential. Antivir Chem Chemother. 14(2): 91-98.

Saxena, S.K., Mishra, N., Saxena, R., Singh, M., and Mathur, A. (2009). Trend of Japanese encephalitis in North India: evidence from thirty-eight acute encephalitis cases and appraisal of niceties. J Infect Dev Ctries. 3(7): 517-530.

Saxena, S.K., Singh, A., and Mathur, A. (2000). Antiviral effect of nitric oxide during Japanese encephalitis virus infection. Int J Exp Pathol. 81(2): 165-172.

Saxena, S.K., Singh, M., Pathak, A.K., and Mathur, A. (2006). Reply to 'Encephalitis outbreak finds Indian officials unprepared'. Nat Med. 12(3): 269-270.

Schuh, A.J., Li, L., Tesh, R.B., Innis, B.L. and Barrett, A.D. (2010). Genetic characterization of early isolates of Japanese encephalitis virus: genotype II has been circulating since at least 1951. J Gen Virol. 91(Pt 1): 95-102.

See, E., Tan, H.C., Wang, D., Ooi, E.E. and Lee, M.A. (2002). Presence of hemagglutination inhibition and neutralization antibodies to Japanese encephalitis virus in wild pigs on an offshore island in Singapore. Acta Trop. 81(3): 233-236.

Shimojima, M., Nagao, Y., Shimoda, H., Tamaru, S., Yamanaka, T., Matsumura, T., Kondo, T. and Maeda, K. (2011).Full Genome Sequence and Virulence Analyses of the Recent Equine Isolate of Japanese Encephalitis Virus. J Vet Med Sci. Jan 11, 2011 [Epub ahead of print]

Sinniah, M. (1989). A review of Japanese-B virus encephalitis in Malaysia. Southeast Asian J Trop Med Public Health. 20(4): 581-585.

Solomon, T. and Winter, P.M. (2004). Neurovirulence and host factors in flavivirus encephalitis--evidence from clinical epidemiology. Arch Virol Suppl. (18): 161670.

Solomon, T., Dung, N.M., Kneen, R., Thao le, T.T., Gainsborough, M., Nisalak, A., Day, N.P.,Kirkham, F.J., Vaughn, D.W., Smith, S. and White, N.J. (2002). Seizures and raised intracranial pressure in Vietnamese patients with Japanese encephalitis. Brain. 125(Pt 5): 1084-1093.

Solomon, T., Ni, H., Beasley, D.W., Ekkelenkamp, M., Cardosa, M.J. and Barrett, A.D. (2003). Origin and evolution of Japanese encephalitis virus in southeast Asia. J Virol. 77(5): 3091-3098.

Spicer, P.E., Phillips, D., Pike, A., Johansen, C., Melrose, W. and Hall, R.A. (1999). Antibodies to Japanese encephalitis virus in human sera collected from Irian Jaya. Follow-up of a previously reported case of Japanese encephalitis in that region. Trans R Soc Trop Med Hyg. 93(5): 511-514.

Srey, V.H., Sadones, H., Ong, S., Mam, M., Yim, C., Sor, S., Grosjean, P., Reynes, J.M.,Grosjean, P. and Reynes, J.M. (2002). Etiology of encephalitis syndrome among hospitalized children and adults in Takeo, Cambodia, 1999-2000. Am J Trop Med Hyg 66(2): 200-207.

Srivastava, S., Khanna, N., Saxena, S.K., Singh, A., Mathur, A., and Dhole, T.N. (1999). Degradation of Japanese encephalitis virus by neutrophils. Int J Exp Pathol. 80(1): 17-24.

Sugiura, T. and Shimada, K. (1999). Seroepizootiological survey of Japanese encephalitis virus and Getah virus in regional horse race tracks from 1991 to 1997 in Japan. J Vet Med Sci. 61(8): 877-881. 
Takahashi, H., Pool, V., Tsai, T.F. and Chen, R.T. (2000). Adverse events after Japanese encephalitis vaccination: review of post-marketing surveillance data from Japan and the United States. The VAERS Working Group. Vaccine. 18(26):2963-2969.

Tandon, A., Singh, A., Atrishi, E., Saxena, S.K., and Mathur, A. (2002). Alteration in plasma glucose levels in Japanese encephalitis patients. Int J Exp Pathol. 83(1): 39-46.

Tewari, S.C., Thenmozhi, V., Arunachalam, N., Philip Samuel, P. and Tyagi, B.K. (2008). Desiccated vector mosquitoes used for the surveillance of Japanese encephalitis virus activity in endemic southern India. Trop Med Int Health. 13(2): 286-290.

Thenmozhi, V., Rajendran, R., Ayanar, K., Manavalan, R. and Tyagi, B.K. (2006). Long-term study of Japanese encephalitis virus infection in Anopheles subpictus in Cuddalore district, Tamil Nadu, South India. Trop Med Int Health. 11(3): 288-293.

Thisyakorn, U. and Nimmannitya, S. (1985). Japanese encephalitis in Thai children, Bangkok, Thailand. Southeast Asian J Trop Med Public Health. 16(1): 93-97.

Ting, S.H., Tan, H.C., Wong, W.K., Ng, M.L., Chan, S.H. and Ooi, E.E. (2004). Seroepidemiology of neutralizing antibodies to Japanese encephalitis virus in Singapore: continued transmission despite abolishment of pig farming? Acta Trop. 92(3): 187-191.

Trosper, J.H., Ksiazek, T.G. and Cross, J.H. (1980). Isolation of Japanese encephalitis virus from the Republic of the Philippines. Trans $R$ Soc Trop Med Hyg. 74(3): 292-295.

Unni, S.K., Růžek, D., Chhatbar, C., Mishra, R., Johri, M.K. and Singh, S.K. (2011). Japanese encephalitis virus: from genome to infectome. Microbes Infect. 13(4): 312-321.

van den Hurk, A.F, Ritchie, S.A, Johansen, C.A, Mackenzie, J.S. and Smith, G.A. (2008). Domestic pigs and Japanese encephalitis virus infection, Australia. Emerg Infect Dis. 14(11): 1736-1738.

van den Hurk, A.F., Johansen, C.A., Zborowski, P., Paru, R., Foley, P.N., Beebe, N.W., Mackenzie, J.S. and Ritchie, S.A. (2003). Mosquito host-feeding patterns and implications for Japanese encephalitis virus transmission in northern Australia and Papua New Guinea. Med Vet Entomol. 17(4): 403-411.

van den Hurk, A.F., Johansen, C.A., Zborowski, P., Phillips, D.A., Pyke, A.T., Mackenzie, J.S. and Ritchie, S.A .(2001). Flaviviruses isolated from mosquitoes collected during the first recorded outbreak of Japanese encephalitis virus on Cape York Peninsula, Australia. Am J Trop Med Hyg. 64(3-4):125-130.

van den Hurk, A.F., Montgomery, B.L., Northill, J.A., Smith, I.L., Zborowski, P., Ritchie, S.A., Mackenzie, J.S. and Smith, G.A. (2006). Short report: the first isolation of Japanese encephalitis virus from mosquitoes collected from mainland Australia. Am J Trop Med Hyg. 75(1): 21-25.

van den Hurk, A.F., Nisbet, D.J., Foley, P.N., Ritchie, S.A., Mackenzie, J.S.and Beebe, N.W.(2002). Isolation of arboviruses from mosquitoes (Diptera: Culicidae) collected from the Gulf Plains region of northwest Queensland, Australia. J Med Entomol. 39(5):786-792.

van den Hurk, A.F., Nisbet, D.J., Hall, R.A., Kay, B.H., MacKenzie, J.S. and Ritchie, S.A. (2003). Vector competence of Australian mosquitoes (Diptera: Culicidae) for Japanese encephalitis virus. J Med Entomol. 40(1): 82-90. 
van den Hurk, A.F., Nisbet, D.J., Johansen, C.A., Foley, P.N., Ritchie, S.A. and Mackenzie, J.S. (2001). Japanese encephalitis on Badu Island, Australia: the first isolation of Japanese encephalitis virus from Culex gelidus in the Australasian region and the role of mosquito host-feeding patterns in virus transmission cycles. Trans $R$ Soc Trop Med Hyg. 95(6): 595-600.

van den Hurk, A.F., Ritchie, S.A. and Mackenzie, J.S. (2009). Ecology and geographical expansion of Japanese encephalitis virus. Annu Rev Entomol. 54: 17-35.

van den Hurk, A.F., Ritchie, S.A., Johansen, C.A., Mackenzie, J.S. and Smith, G.A. (2008). Domestic pigs and Japanese encephalitis virus infection, Australia. Emerg Infect Dis. 14(11): 1736-1738.

Victor, T.J., Malathi, M., Ravi, V., Palani, G. and Appavoo, N.C. (2000). First outbreak of Japanese encephalitis in two villages of Dharmapuri district in Tamil Nadu. Indian J Med Res. 112: 193-197.

Wang, H.Y., Takasaki, T., Fu, S.H., Sun, X.H., Zhang, H.L., Wang, Z.X., Hao, Z.Y., Zhang, J.K., Tang, Q., Kotaki, A., Tajima, S., Liang, X.F., Yang, W.Z., Kurane, I. and Liang, G.D. (2007). Molecular epidemiological analysis of Japanese encephalitis virus in China. J Gen Virol. 88(Pt 3): 885-894.

Weaver, S.C. and Reisen, W.K. (2010). Present and future arboviral threats. Antiviral Res. 85(2): 328-345.

Whitley, R.J. and Gnann, J.W. (2002). Viral encephalitis: familiar infections and emerging pathogens. Lancet. 359(9305): 507-513. Review.

Widjaja, S., Soekotjo, W., Hartati, S., Jennings, G.B. and Corwin, A.L. (1995). Prevalence of hemagglutination-inhibition and neutralizing antibodies to arboviruses in horses of java. Southeast Asian J Trop Med Public Health. 26(1): 109-113.

Wong, S.C., Ooi, M.H., Abdullah, A.R., Wong, S.Y., Krishnan, S., Tio, P.H., Pek, P.C., Lai, B.F.,Mohan, A., Muhi, J., Kiyu, A., Arif, M.T. and Cardosa, M.J. (2008). A decade of Japanese encephalitis surveillance in Sarawak, Malaysia: 1997-2006. Trop Med Int Health. 13(1): 52-55.

Yamanaka, A., Mulyatno, K.C., Susilowati, H., Hendrianto, E., Utsumi, T., Amin, M., Lusida, M.I., Soegijanto, S. and Konishi, E. (2010). Prevalence of antibodies to Japanese encephalitis virus among pigs in Bali and East Java, Indonesia, 2008. Jpn J Infect Dis. 63(1): 58-60.

Yang, D.K., Kim, B.H., Kweon, C.H., Nah, J.J., Kim, H.J., Lee, K.W., Yang, Y.J. and Mun, K.W. (2008). Serosurveillance for Japanese encephalitis, Akabane, and Aino viruses for Thoroughbred horses in Korea. J Vet Sci. 9(4): 381-385.

Yang, D.K., Kweon, C.H., Kim, B.H., Hwang, I.J., Kang, M.I., So, B.J. and Cho, K.O. (2007). The seroprevalence of Japanese encephalitis virus in goats raised in Korea. J Vet Sci. 8(2): 197-199.

Yen, NT., Duffy, MR., Hong, NM., Hien, NT., Fischer, M. and Hills, SL. (2010). Surveillance for Japanese encephalitis in Vietnam, 1998-2007. Am J Trop Med Hyg. 83(4): 816-819.

Zhang, D.L., Ma, L.B., Fu, S.H., Wang, L.H., Wang, H.Y., Zhang, M., Wei, Z.G., Li, G.G., Cui, X.F., Lei, H.G., Sun, X.H., Lv, X.J., Li, M.H. and Liang, G.D. (2008). [Clinical characteristics and laboratory assay of adult Japanese encephalitis patients in an outbreak in Yuncheng, Shanxi Province, 2006]. Zhonghua Shi Yan He Lin Chuang Bing Du Xue Za Zhi. 22(2): 95-97. 
Zhang, J.S., Zhao, Q.M., Zhang, P.H., Jia, N. and Cao, W.C. (2009). Genomic sequence of a Japanese encephalitis virus isolate from southern China. Arch Virol. 154(7): 11771180.

Zimmerman, M.D., Scott, R.M., Vaughn, D.W., Rajbhandari, S., Nisalak, A. and Shrestha, M.P. (1997). Short report: an outbreak of Japanese encephalitis in Kathmandu, Nepal. Am J Trop Med Hyg. 57(3): 283-284. 


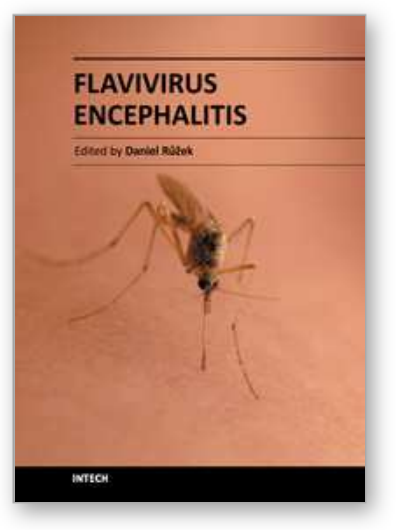

\author{
Flavivirus Encephalitis \\ Edited by Dr. Daniel Ruzek
}

ISBN 978-953-307-669-0

Hard cover, 478 pages

Publisher InTech

Published online 30, September, 2011

Published in print edition September, 2011

Encephalitis is an inflammation of the brain tissue associated with clinical evidence of brain dysfunction. The disease is of high public health importance worldwide due to its high morbidity and mortality. Flaviviruses, such as tick-borne encephalitis virus, Japanese encephalitis virus, Murray Valley encephalitis virus, or St. Louis encephalitis virus, represent important causative agents of encephalitis in humans in various parts of the world. The book Flavivirus Encephalitis provides the most recent information about selected aspects associated with encephalitic flaviviruses. The book contains chapters that cover a wide spectrum of subjects including flavivirus biology, virus-host interactions, role of vectors in disease epidemiology, neurological dengue, and West Nile encephalitis. Special attention is paid to tick-borne encephalitis and Japanese encephalitis viruses. The book uniquely combines up-to-date reviews with cutting-edge original research data, and provides a condensed source of information for clinicians, virologists, pathologists, immunologists, as well as for students of medicine or life sciences.

\title{
How to reference
}

In order to correctly reference this scholarly work, feel free to copy and paste the following:

Shailendra K. Saxena, Sneham Tiwari, Rakhi Saxena, Asha Mathur and Madhavan P.N. Nair (2011). Japanese Encephalitis: An Emerging and Spreading Arbovirosis, Flavivirus Encephalitis, Dr. Daniel Ruzek (Ed.), ISBN: 978-953-307-669-0, InTech, Available from: http://www.intechopen.com/books/flavivirusencephalitis/japanese-encephalitis-an-emerging-and-spreading-arbovirosis

\section{INTECH}

open science | open minds

\section{InTech Europe}

University Campus STeP Ri

Slavka Krautzeka 83/A

51000 Rijeka, Croatia

Phone: +385 (51) 770447

Fax: +385 (51) 686166

www.intechopen.com

\section{InTech China}

Unit 405, Office Block, Hotel Equatorial Shanghai

No.65, Yan An Road (West), Shanghai, 200040, China

中国上海市延安西路65号上海国际贵都大饭店办公楼405单元

Phone: +86-21-62489820

Fax: $+86-21-62489821$ 
(C) 2011 The Author(s). Licensee IntechOpen. This chapter is distributed under the terms of the Creative Commons Attribution-NonCommercialShareAlike-3.0 License, which permits use, distribution and reproduction for non-commercial purposes, provided the original is properly cited and derivative works building on this content are distributed under the same license. 